\title{
Research On Library Service Quality Optimization Under "Reader-centered"
}

\author{
Jin Jin \\ Harbin Institute of Technology \\ Harbin, Heilongjiang 150001, China
}

\begin{abstract}
Since the 1990s, libraries gradually established the service concept of "Reader-centered". In practice, however, many libraries still can not get rid of the traditional philosophy shackles of "Literature-centered". This paper analyzed the main performance of poor implement on the concept of "Reader-centered" in the library, gave the concept of "Reader-centered" to optimize the service quality of the library to provide a reference for the library staff.
\end{abstract}

Keywords: Reader-centered; Library; Service quality

\section{RESOLVE THE SERVICE CONCEPT OF "READER- CENTERED"}

The library is an important place for people to borrow books, access to information. It is an important position in the field of culture and education. Libraries have always been "Literature-centered". Its main job is to purchase the literature, collection,preservation and finishing. However, that for reader's library lending service is not the working center.

In the 1990s, the gradual rise of the Internet has greatly expanded the way for people to acquire knowledge. Libraries is in danger of being replaced by the Internet's information agency. Libraries academia reexamine the status and role of libraries in the field of human knowledge,raised the concept of concerning about readers, concerning about the service importance. In 1998, Mr. Wu Jianzhong in his monograph "21st Century Library New Theory" said "The focus should shift from library books to the people". This concept has been recognized by library academia. They concluded that the focus should be transferred from the "literature-centered" to "reader-centered".

"Reader-centered" is to ask the library to considered the needs of readers as starting point and the end result of all the library work. Establish the dominant position of the reader, maintain the reader's basic interest in order to improve the quality of service for readers.

\section{THE MAIN PERFORMANCE OF POOR IMPLEMENT ON} THE CONCEPT OF "READER-CENTERED" IN THE LIBRARY

Although the vast majority of libraries have established a "reader-centered" service concept, however, implement in practice is often not well done.Mainly for:

\section{A. Purchase books}

Some of the library purchase books work was entirely borne by librarians. However, since librarians are neither the specialized teachers nor the students who need books. So they did not know the school's curriculum and professional

settings. The purchase of books and actual demand have big differences. Readers often find that lot-need books is low in the number of book collections.

\section{B. Communication ways}

In order to better strengthen communication between libraries and readers many colleges and universities opened guest book, web messages and other communication methods. However, today's new media increasingly developed, and the traditional way of seem monotonous and backward, so communication efficiency is very low.Libraries should strengthen ties with readers.

\section{Training readers}

Almost all college would carry out training courses for freshmen to use library. However, such programs often fail to truly reach "reader-centered". Training often does not include high school readers'need of writing papers document retrieval course. This also led to a lower quality of student essays.

\section{Quality of the librarian}

Many college librarians failed to correctly establish a service concept of "reader-centered". They only consider the convenience of their own work, which injury readers' enthusiasm. They face the reader's consult with sarcastic comments, love to ignore, and injured readers'enthusiasm. Some librarians have low public morality, disturb public order and damage the environment.

\section{IMPLEMENT COUNTERMEASURES TO THE CONCEPT OF "READER-CENTERED"}

To solve these problems we gave the concept of " Reader-centered" to optimize the service quality of the library to improve library service quality, as follows:

\section{A. Improved the ways to buy}

Library books' purchase is the most basic and most important work. However, because they do not clearly understand the type and number of required bibliographies, resulting in a selected bibliography irrational structure and it needs to be optimized.

This requires purchase committee through a variety of ways(including students and teachers)to strengthen ties with readers. Understand the school's professional settings and disciplines setting, understand the needs of readers and research. 
On the other hand, the readers'recommend is also an important method to purchase for library improvements. Libraries should promptly purchase to optimize the the number of collections and better serve for readers. For example in China University of Technology Library, readers can recommend the library to buy bibliography by phone, voice mail, e-mail, BBS, voluntary associations and other methods. Readers recommend 26,000 books, in which about 19,000 books have been ordered or collected.

\section{B. Increase communication pathways}

The traditional means of communication(online guest book and leave a message)exchange efficiency is low. Today, many colleges and universities have set up a library official micro-blog platform and the official micro-channel public platform. They in time output library-related news, timely keep communication with readers, and achieved good results.

Tsinghua University Library is the leader in University Library official micro-blogging. Its number of fans is more than 40,000, covering almost all the teachers and students. Readers can easily understand their loan situation, and it is very convenient.

Mobile Internet has changed the way of people's communication. Libraries should take full advantage of the power of new media to strengthen communication with readers.

\section{Strengthen readers'education}

Readers'education is an important part of library work, which can educate readers better to use library resources, lay a good foundation for readers in scientific research. However, readers education conducted by many universities was only for freshmen, so many readers gained poor educational results.

Libraries should carry out user education for high school students as well as faculty members.

They may want to search for relevant reference for the study of a topic. They need rich and practical literature search skills. It is necessary to deepen the reader education, carry out literature search training for libraries. For staff readers, libraries should also expand the appropriate training. Many staffs because of habit, are not familiar with computer operations.

Trainers should with "reader-centered" guide staff patiently and meticulously.

\section{Improve the quality of librarians}

Quality of the librarian is the most direct expression of the service concept "reader-centered". Many librarians have low quality, which seriously hindered improving the quality of library services. Library should strengthen professional ethics education,making librarians to establish the service concept of "reader-centered". Library should strengthen librarian professional quality education, making librarians are familiar with collections and master the use of various search tools, to provide quality services to readers more quickly and accurately. Libraries should enhance the cultural quality of training to librarians and be familiar with modern technology. They should understand schools professional setting and research dynamic, to provide readers with accurate, high-quality service.

\section{CONCLUSION}

Service for the reader is the core content of library work. Library should firmly establish the service concept of "reader-centered", and carefully finish it in practice. Only in this way can they meet the needs of the readers and better optimize library service quality. Then they could make library become an accelerator to promote readers to gain more progress.

\section{REFERENCES:}

[1] Ding Qinzhen. New library service quality commitment with "readercentered"[J]. Research of the city development. 2013 .1.

[2] Liu Jingchun. With"reader-centric" the strategy to improve college libraries services quality[J]. Yangzhou Education College. 2012.2.

[3] Li Weihai. Library Research about"reader-centered"--University Library Services change, organizational restructuring and staff development[D]. East China Normal University. 2005

[4] Wang Yan. Reader-based library management process optimization[J]. Library Forum. 2012. 2.

[5] Li Wen, Li Guowu. Make reality more close from ideal to talk about the library "reader-centered" again[J]. University Library. 2013.15. 